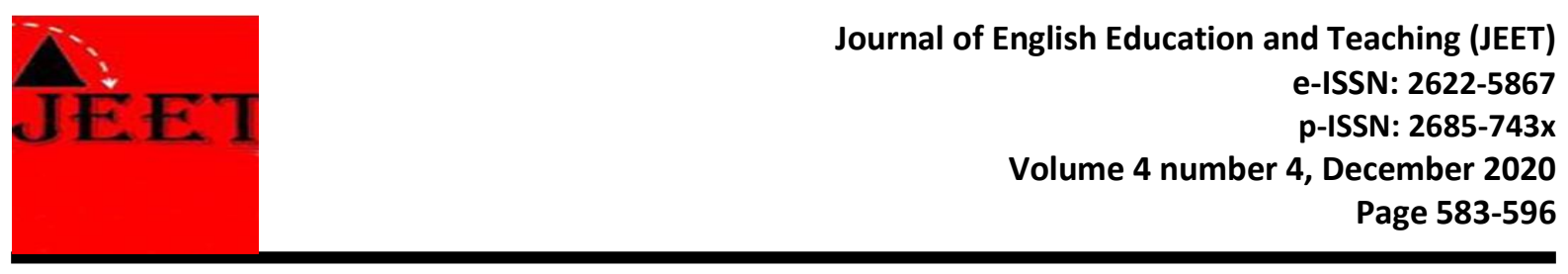

\title{
Teaching Reading on English for Specific Purposes with Think-Pair-Share Technique
}

\author{
Fatchul Mu'in \\ Universitas Lambung Mangkurat \\ fatchul_muin@ulm.ac.id \\ Rizky Amelia \\ Universitas Lambung Mangkurat \\ rizky.amelia@ulm.ac.id \\ Raisa Fadilla \\ Universitas Lambung Mangkurat \\ raisa.fadilla@ulm.ac.id \\ Eka Puteri Elyani \\ Universitas Lambung Mangkurat \\ eka.elyani@ulm.ac.id \\ Corresponding email: fatchul_muin@ulm.ac.id
}

\begin{abstract}
Different departments in a university have different terms with general English. English for Specific Purpose (ESP) helps students with different departments learn specific terms. Social studies study program is one of the majors that its students find it rather hard to comprehend the content and terms related to their major. Think-Pair-Share (TPS) on reading helps develop students' ability to understand the text. This study is aimed to find out the difference between the students who are taught using ESP text with Think-Pair-Share (TPS) Technique and those who are not taught with the TPS technique. This study employs a quasi-experimental design. The study objects were the social studies study program students, classified into experimental and control groups. The research instruments were related to social studies in English passages. Posttest data were calculated and used to determine the treatment's effectiveness or any significant difference in each group. The data were analyzed by an analysis of variance (ANOVA) to test the hypotheses. The study results reveal that experimental and control classes have a significant difference in the mean; 76.63 is an experimental group mean higher than the control group mean that was 74.64. It shows that the students who used the Think-Pair-Share technique had better reading comprehension on ESP text than the students who did not use the technique. This is due to the implementation's steps that emphases students' performance and togetherness on doing their activities in the classroom activities to develop their ability in language skills. This study is expected to provide new insight into English for specific purposes and give valuable experience in teaching reading for specific social studies. This research is also proposed some new vocabularies related to social studies to the students. Thus, this study gives sight and information about English reading texts based on social studies.
\end{abstract}

Keywords: English for Specific Purposes, teaching reading, Think-Pair-Share 


\section{Introduction}

One of the English users is university students, as they need it to support their university learning. It cannot be avoided that every department's literature in the university is written in English. Reading with a purpose, whether for entertainment, information, or research, motivates the readers (Bojovic, 2010). Reading is a purposeful, interactive, complex, comprehending, and flexible activity that takes extensive time and resources to be developed (Bojovic, 2010; Martina, et al. 2020; Adeani, et al. 2020; Martina, et al. 2020; Handayani, et al. 2020; Wibowo, et al. 2020). So far, English as a general basic course relies on the General English Course. Most materials are oriented in English grammar, and reading texts only covers general subjects.

Meanwhile, English as a general basic course is intended to introduce English for specific purposes. Most of the books available cover structure items, such as tenses, clauses, passive/active voice, etc. Each section is equipped with a series of structure practices and reading texts with general subjects. Generally, the English class as a general basic course is large, consisting of more than 50 students.

Generally, the English class as a general basic course is large, consisting of more than 50 students. The suitable methods for teaching English in a large class are lecturing and providing assignments. However, such methods are not able to lead students to achieve optimal results. The provision of material in the form of grammar and general reading texts was also unable to lead students to gain experience and knowledge about English for Specific Purposes according to the study program from which they attended their study.

Dealing with this situation, some students still are not familiar with the related terms to their department. The students need to master the terms related to their major to make them easy to understand the terms they frequently find in their learning. Hyland (2002) argues that taking specificity on the language teaching seriously makes it more effective. Basturkmen (2010) also emphasize prioritizing the competencies related to students' field focuses on when, where, and why they need the language.

Bracaj (2014) defines that learning English for a certain subject or career is called English for specific purposes. It is "the instruction of English according to 
authentic and the needs of students who have to accomplish real-life tasks that are separated from simply passing an English class or exam (Smoak, 2003 in Mothejzíková, 2014). English for Specific Purposes (ESP) emphasizes language in context. ESP is offered to the students from different departments to learn specific terms in their department. ESP courses focus on students' needs (Pradhan, 2013). It can guide the students to learn based on their needs in learning English. English for Specific Purpose (ESP) serves the students with the materials that fit their major. Pradhan (2013) claims that the approach of language-centered and learningcentered on the design of a course is the outcomes of ESP's origin, in which the students will determine the learning. Therefore, English for Specific Purposes (ESP) focuses on language needs rather than the general language. ESP classes emphasize the need for both the structure and lexis for a certain field and the types of activities students are expected to do within the career.

Among many universities, social studies are among the majors that mostly use English in teaching and learning. According to the preliminary research conducted at the social studies study program of Teacher Training and Education Faculty, University of Lambung Mangkurat, students find it challenging to comprehend the content and terms related to their major when reading general English surrounds them. Benabdallah (2013) stated that teaching reading aims to understand questions and focuses on content-based themes to give students' understanding of the range of topics and some different sets of terminology required to be used appropriately in their field. It hinders some students from being confused about what they are reading. Two roles of the reading approach on English for Specific Purposes (ESP) are modifying the text as a linguistic object to the text as a vehicle of information and recognizing that good reading requires language and skills. Moreover, the reading component of an ESP course requires a balance between skills and language development. Some of the crucial skills to be learned or transferred into the new language are: selecting what is relevant for the current purpose; skimming for content and meaning; scanning for specifics; identifying organizational patterns; understanding relations within a sentence and between sentences, and using cohesive and discourse markers (Bojovic, 2010).

Therefore, there is a need to serve the students with appropriate reading materials related to their department to familiarize them with the terms. These materials should function as links between already learned ('existing knowledge') 
and new information. Three important standards need to be considered to select a text: (1) appropriateness of the context consisting of the various reading texts derived from many sources, (2) readability of the chosen texts, and (3) exploitability of the content of the text which is suitable on developing students' comprehension strategies (Nuttal, 2000; Yunita et al., 2017).

Also, techniques of teaching reading influence the readers. The correct technique will make the reading process is enjoyable. Cooperative learning on reading helps students to have a pleasant reading process. One of the cooperative learning methods used is the TPS technique in reading, which helps students develop their ability to understand the text. Faisal's study (2014) reveals that TPS can improve students' learning outcomes in reading achievement. Moreover, Nugraha (2018) claims that the TPS procedure substantially results in students' reading achievement.

TPS is one of the cooperative learning types developed by Frank Lyman at Maryland University. TPS is a learning procedure in a small group discussion with two members so that the students' participation will be increased and easy to adapt to at school. It has a procedure that gives students additional time to think, respond, and help each other.

According to Kholik (2012), some benefits of TPS are that (1) it is easily carried in a large class, (2) it provides enough time for students to reflect on the content of the subject matter, (3) it brings a good relationship to the whole class; students listen to each other, and a good discussion with good quality answers will happen, (4) it provides the students quality time to practice before issuing an opinion, which is shared by small groups or the whole class, teachers have more time to think when they are using TPS. They can concentrate on listening to the students' answers, observing the students' reactions, and identifying the students' qualifying questions.

According to the explanation mentioned above, Based on the illustration above, this research is intended to: (1) find out the difference between the students who are taught using ESP text with Think-Pair-Share (TPS) Technique and those who are not taught with the TPS technique, and (2) to know the students' perspectives on Learning English for Special Purposes (ESP)

\section{Research Methodology}


The research design which aims at measuring the effectiveness is the experimental research design. However, as the subjects could not be randomly assigned, this current study employed a quasi-experimental design since the random assignment was not feasible to be executed in the educational setting (Joyner, Rouse, \& Glatthorn, 2013:75).

The research was carried out at Lambung Mangkurat University. The participants are the undergraduate students of the social studies program study separated into two groups, experiment and control groups. An experiment group is a group that was given treatment; in this case, TPS Technique; moreover, the control group is a group that was taught by lecturing. For the experimental group, there are three steps done to apply the Think Pair and Share (TPS):

Step 1 : Thinking, the teacher gives questions or issues related to the lesson, and then students ask to think about the questions or issues independently for some time.

Step 2 : Pairing, the teacher asks students to pair with the other students to discuss their thought in the first step. It is expected that students can share the answer if a question had identified.

Step 3 : Sharing, the teacher asks pairs to share what they have talked about with the entire class. Effective to be done by pairs by pairs one another and continued until half pairs have chances to the presentation.

In the TPS procedure, learners were asked to think about their answers based on a given time. Other students answer them, and the discussion continued. Students also had chances to share with their friends about their answers before they had been asked to give their ideas to the class. All students shared their thought at least with one student. Students respond in the big group after they share with their partners.

This research used a test and a questionnaire as the instruments to obtain the data. Reading on English for Specific Purposes (ESP) text related to social studies, English passages was used to measure students' reading skills. A questionnaire was used to know students' points of view towards English for specific purposes (ESP). In the posttest, they were requested to answer the test as it is instructed. The test was scored. The students' names on the test were hidden, and the test result was coded to avoid subjectivity. The learners were identified by A and B code, which A was 
control group learners, and B was experiment group learners. These post-test data were calculated and used to determine the treatment's effectiveness or any significant difference in each group.

In the data analysis, the first step was to conduct preliminary statistics by analyzing the data for fulfilling the statistical assumptions on the homogeneity and normality testing. The second step in the data analysis tested the hypotheses by deploying an analysis of variance (ANOVA) test using the SPSS 18.0 program. Finally, the last step in the data analysis was deciding on accepting or rejecting the null hypothesis.

\section{Results of Experiment and Control Groups' Post-test}

All collected data are presented in this chapter section by section, starting from both groups' descriptive statistics to the hypotheses testing.

Table 1. Descriptive Statistics of Post-test

\begin{tabular}{|l|c|c|c|c|c|c|c|c|}
\hline & $\mathrm{N}$ & Mean & $\begin{array}{l}\text { Std. } \\
\text { Deviati } \\
\text { on }\end{array}$ & Std. Error & \multicolumn{2}{|l|}{$\begin{array}{l}\text { 95\% Confidence } \\
\text { Interval for Mean }\end{array}$} & Min. & Max. \\
\hline & & & & & $\begin{array}{l}\text { Lower } \\
\text { Bound }\end{array}$ & $\begin{array}{l}\text { Upper } \\
\text { Bound }\end{array}$ & & \\
\hline Control & 37 & 74,6486 & 4,13129 &, 67918 & 73,2712 & 76,0261 & 65,00 & 81,00 \\
\hline Exp & 33 & 76,6364 & 3,59529 &, 62586 & 75,3615 & 77,9112 & 65,00 & 85,00 \\
\hline Total & 70 & 75,5857 & 3,98727 &, 47657 & 74,6350 & 76,5364 & 65,00 & 85,00 \\
\hline
\end{tabular}

The descriptive statistics for both groups are presented in Table 1. The mean scores for experiment and control groups are 74.64 and 76.63, respectively. The fulfillment of the statistical assumption aims to determine the data, whether it can be further used for hypotheses testing or not. Among some statistical assumption tests, two tests are used in this study, namely homogeneity and normality. All the testing was conducted utilizing the SPSS 18.0 program. The results are presented in Table 2 and Table 3.

Table 2. Homogeneity of Variances Test Levene

\begin{tabular}{llll} 
Statistic & df1 & df2 & Sig. \\
2,521 & 1 & 68 &, 117 \\
\hline
\end{tabular}

Both groups are homogeneous. The $F=2.521$ has a probability of .117 , which is higher than the significance level proposed by researchers .05. Therefore, there 
was enough evidence to state that both groups have a homogeneous variance.

Normality testing used the Kolmogorov-Smirnov test to decide that the collected data came from the normal distribution groups. Table 4.3 provides the results of normality testing.

Table 4.3 Test of Normality

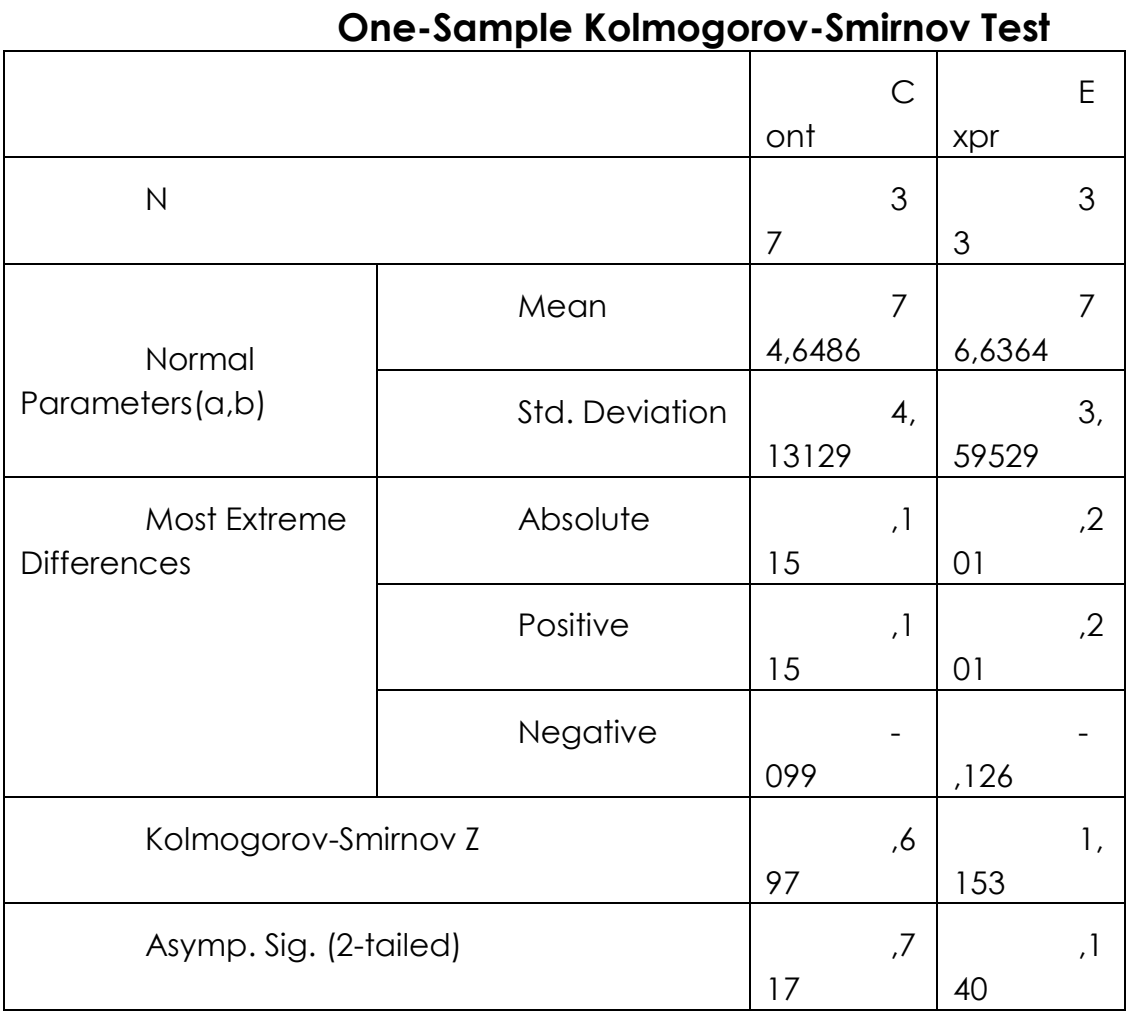

The normality testing results using the Kolmogorov-Smirnov test show that the levels of significance are .717 and .140 in which are higher than the significant level of .05. It is assumed that the experiment and control groups' data were normally distributed.

The next step was testing the hypotheses. The ANOVA test was employed by using SPSS 18.0 program to prove the questions of the research. The null hypothesis of this research question was, "There is no significant difference in students' reading comprehension taught by using ESP text with TPS Technique than those who are taught by using ESP text with lecturing." Meanwhile, the alternative hypothesis of the research question was, "The students who are taught by using ESP text with TPS Technique have better reading comprehension compared to those who are taught by using ESP text with lecturing." The results of the ANOVA test to evaluate this null hypothesis is shown in Table 4. 
Table 4. Results of Post-test

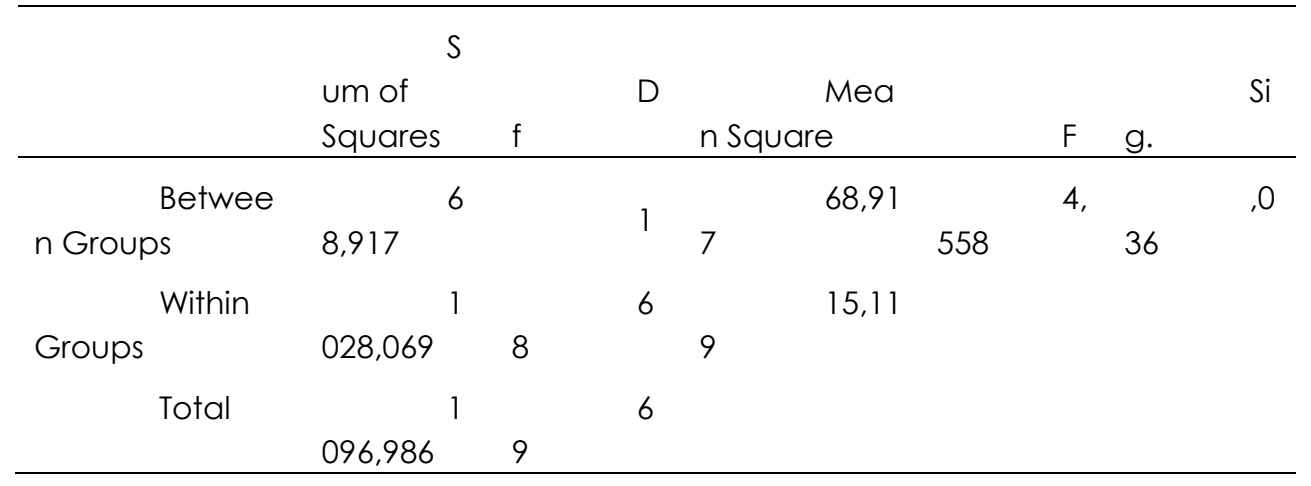

The ANOVA test result shown in Table 4 revealed that a difference between groups is significant. Technically speaking (F4.558, $p=.036$ ) proved to be significant at the .05 level. In other words, the p-value is lower than .05 , the mean significant difference $(.036<.05)$. Therefore, there was not enough evidence to accept the null hypothesis. It is assumed that the alternative hypothesis is accepted. From the result, it is established that the ESP text, which is taught by using TPS Technique, gives better comprehension to the students.

\section{Discussion}

\section{a. Students' Perspectives toward Learning English for Specific Purposes (ESP)}

Both groups were given questionnaires to determine how the students perceived the learning of English for Specific Purposes. There were 69 students in total.

The data analysis results were perceived as various answers from the students regarding their perspectives toward the importance of learning ESP, the purpose of learning ESP, the motivation in learning ESP, the way to learn ESP, and the preference for learning specific skills in ESP. Regarding the first item, the importance of learning English, 36 students stated that ESP is essential for them, while 33 students mentioned ESP is vital. Interestingly, no one responded that English is not important at all. Next, another item of the questionnaire found out the aim of learning ESP by the students. It is shown that a high number of students (65\%) learn ESP to improve their marks at their educational institution; on the other hand, the rest of the students (35\%) study ESP for pleasure.

Furthermore, it can be viewed that the motivation for learning ESP by the 
students is varied. It represents that $61 \%$ and $36 \%$ of students have high and moderate motivation, respectively, while interestingly, $3 \%$ are non-motivated. Moreover, the preferable way to learn ESP is also assessed on the questionnaire. A high number of students (83\%) prefer to learn ESP in the group; meanwhile, only a few students stated that they like to study ESP individually. Lastly, regarding the particular skills students want to study the most, 32 students chose reading as the essential skill they need to learn and master, while 18 students wish to listen to be studied further. Besides, 24 students want to learn speaking other than other English skills, and only eight students prefer to study more about how to write in English. It can be concluded that English's receptive skills are more likely to be learned by the students than productive skills.

\section{b. The Effects of TPS on Comprehending Reading Text}

Based on these research findings, it is proven that TPS's application gives students a good impact on comprehending reading text. It can be seen from the findings that the rough result on the mean of the experiment group is 76.63, higher than the control group mean that is 74.64. These scores indicated that the experiment group has a better performance compared to the control group.

Furthermore, it is evident from the ANOVA computation result, which showed that the obtained p-value/sig is .036 is smaller than .05. The first null hypothesis of this study is rejected. It shows that the learners who used the TPS Technique have better reading comprehension performance on ESP text than the students who did not use the technique.

Referring to the relevant theories and previous studies on good impacts of TPS Technique on reading comprehension, this research findings supported some studies by Martina Susanti (2017), Goodman (2010), Astiyandha (2013), and Faisal (2014) that state TPS Technique helps students in boosting their comprehending on reading text. TPS Technique can be a choice for teachers' activity in teaching reading due to its effectiveness that has been empirically found. It is under some earlier studies, for example, The Effect of Using TPS during Reading Comprehension by Martina Susanti (2017). The research aimed to describe the effects of the implementation of TPS Strategy during Guided Reading Lessons on reading achievement. Based on the findings, the similarity is found in this study and Martina Susanti's study that the TPS Technique positively contributes to learners' comprehension of reading text.

However, the differences are also found in these two studies. This study was 
intended to determine ESP text's effectiveness on social studies students with the TPS technique while Martina Susanti (2017) study focused on The Effectiveness of Think Pair Share Strategy Toward Students' Reading Comprehension. Yet, still, both of these studies showed the same positive findings. Regarding the use of materials, even though both studies' main focus was reading comprehension, there is still a significant difference between these two studies. This study focused on the ESP text on social studies. At the same time, Martina Susanti (2017)emphasized on Reading Comprehension. The consideration of using ESP text as the materials for reading was based on the preliminary study conducted on the social studies of Teacher Training and Education Faculty, Lambung Mangkurat University, and students find it difficult to comprehend the content and terms related to their major when reading as General English always surrounds them. As Benabdallah (2013) stated in his study about strands in teaching reading for social sciences, teaching reading aims to comprehend what is needed to answer and respond and what is required to recognize and understand the required field.

As a part of the cooperative learning strategy, TPS is stated as an effective teaching technique. TPS boosts learners' reactions and responses, helping them do the duty rather than only replying to the teacher (Richards and Rodgers, 2001:198). The effectiveness works on this technique is shown by the application stages that emphasize the learners' performance skill and togetherness in doing all the classroom activities to develop their language skills competence. Barkley (2005:104) describes the steps of implementing the TPS technique. In the first step, the teacher chances learners with a question; the second step provides time for students to keep thinking about a response; then requests students to share their ideas with their partners. This technique gives opportunities for learners to share their thought at least with one learner. It provides advantages to teaching and learning, especially to the learners that it can improve their confidence in learning since they do not work as an individual, yet, as a group. It is supported by Kholik (2012) mentioning that the TPS technique brings a good relationship to the whole class; students listen to each other, and a good discussion with good quality answers will happen. Besides, TPS also gives students the advantage of accepting friends, supporting, academic prestige, self-respect, and increasing student interest. On the other hand, the educator's benefits are having more time to do other tasks and improving learners' contributions to class discussions. The class will be actively involving teachers and 
learners in the class discussion.

\section{c. Students' Perspectives toward ESP Learning}

To have a more significant impact, English for Specific Purposes (ESP) must be planned and implemented to meet students' needs adequately. ESP is the teaching of English according to the real-life task and learners' needs "(Smoak, 2003 in Mothejzíková, 2014). Regarding the teaching of ESP, students' perspectives toward learning ESP, specifically on the importance of learning ESP, the purpose of learning ESP, the motivation in learning ESP, the way to learn ESP, and the preference of learning specific skills in ESP are necessary to be investigated and discussed further.

Pointing out the importance of learning ESP, most students agreed that ESP is needed to be learned at their educational institution. In line with this, ESP is mostly focused on teaching or studying English for a specific job (Bracaj, 2014). Hence, these research findings indicate that students already apprise and realize the benefit of learning ESP. Moving to learn ESP, most students consider learning ESP only for improving their marks at their educational institution. ESP is a requirement subject taught at Lambung Mangkurat University.

Interestingly, students learn ESP to get a satisfying result at the end of the semester, not because they realize that ESP is necessary for their future careers. According to Ahmed (2014), ESP refers to English as a second language or foreign language or Native Speaker, where the learners' goal is to use English in a particular domain.

Regarding learning ESP, almost all students are motivated to learn and join ESP classrooms though very few are non-motivated. It can be assumed that since ESP focuses more on real-life tasks, it will be more challenging and exciting for students to do ESP activities. It is stated that ESP subject emphasis on the particular field and learners' needs (Pradhan, 2013). It can guide the students to learn based on their needs in learning English. English for Specific Purpose (ESP) serves the students with the materials that fit their major. Language-centered and learningcentered approaches are ESP outcomes that rely on learners' needs in studying (Pradhan, 2013). It infers that students only learn about the language itself and learn about taking English benefits in their real-life, especially their career.

Furthermore, most students prefer to work in a group rather than individually 
when learning ESP. It implies that when constructing knowledge about ESP, they need to share and interact with each other to make sense of their learning. It is in line with what Kholik (2012) states that it is beneficial to bring good relationships to the whole class; students listen to each other, and a good discussion with good quality answers will happen. Lastly, most students claimed that receptive skills (listening and reading) are preferable for learning ESP than productive skills (speaking and writing). Since their majors are social studies, they may get more difficulty understanding receptive skills than productive skills because they get used to doing practical tasks rather than theoretical ones. That is why most students feel the need to learn receptive skills more than productive skills.

\section{Conclusion and Implications}

Based on the research findings, some conclusions are drawn in this study. Generally, this study concludes a positive finding that TPS Technique is a useful technique implemented on comprehending reading on ESP text. It is proved by the results of learners' comprehension of the experiment group who were given the TPS technique outperforms the students of the control group who were not given the treatment. Furthermore, TPS Technique is applicable for large classes and benefits the teacher to manage the classroom since it requires students to work in pairs rather than individually. It also boosts learners' confidence when learning English, especially for non-English Department students. Besides, the high intensity of interaction among learners is created as TPS also gives learners an advantage in accepting friends, supporting, academic prestige, self-respect, and increasing learner interest. Therefore, learners acquire more real-life tasks, and they have more actively participated in the class discussion.

Regarding learners' perspectives toward learning ESP, most of the students consider learning ESP is essential. However, recognizing the importance of ESP does not get along with students' purpose in learning ESP. Realizing the importance of ESP, learners are motivated when learning and joining ESP classrooms, specifically when doing activities in the group. For specific skills to be learned in ESP, most learners prefer to study more receptive skills than productive skills. 


\section{References}

Adeani, I. S., Febriani, R. B., \& Syafryadin, S. Using GIBBS reflective cycle in making reflections of literary analysis. Indonesian EFL Journal (IEFLJ). 6(2), 139-148.

Ary, D., Jacobs, L. C., Sorensen, C. \& Razavieh, A. (2010). Introduction to research in education. Belmont, CA: Wadsworth.

Astiyandha, T. (2013). The Effectiveness of Think-Pair-Share Method to teach reading comprehension viewed from students' motivation. Unpublished Thesis, Solo: Sebelas Maret University.

Barkley F. Elizabeth. (2005). Collaborative learning techniques. San Francisco: John Willey.

Basturkmen, H. (2010). Developing courses in English for specific purposes. New York, NY: Palgrave Macmillan.

Benabdallah, A. (2013). Strands in Teaching Reading for Social Sciences: Change and Innovation. English for Specific Purposes World, 14 (38) http://www.espworld.info.

Bracaj, Morena. (2014). Teaching English for specific purposes and teacher training. European Scientific Journal,10 (2), 1-10.

Bojovic, M. (2010). Reading skills and reading comprehension in English for specific purposes. The International Language Conference on the Importance of Learning Professional Foreign Languages for Communication between Cultures, 1-6.

Brown, H. Douglas. (2015). Teaching by principles: An Interactive approach to language pedagogy. Englewood Cliffs, New Jersey: Prentice Hall, Inc

Carmena, Jorge Merino. (2014). From general English to English for Specific Purposes: Looking into students' needs in advanced language recycling courses (English). Published Thesis. Cordoba: Universidad D Cordoba

Ellen, D. Reading comprehension strategies for English language learners. (retrieved from http://www.learnnc.org/lp/pages/724 on January 26, 2011)

Faisal, I. (2014). The use of learning model of Think-Pair-Share in improving students' reading skills ability (A classroom action research at Grade 2 Semester 1, SMPN 3 Simeulve Barat). Unpublished Thesis. Banda Aceh: Universitas Syiah Kuala.

Creswell, J.W. (2015). Research design qualitative, quantitative, and mixed methods approaches. Los Angeles: Sage

Goodman, E. J. (2010). Active research on active learning strategies. Retrieved from:http://www2.uwstout.edu/content/lib/thesis/2010/2010goodmanj.pdf. Retrieved: December 17, 2016.

Haicha, Yassamina. (2013). Teaching reading for specific economic purposes: Identifying criteria for text selection. English for Specific Purposes World, 14(39), $1-11$.

Handayani, S., Youlia, L., Febriani, R.B., Syafryadin, S. (2020). The use of digital literature in teaching reading narrative text. Journal Of English Teaching, Applied Linguistics And Literatures (JETALL). 3(2), 65-74.

Harrabi, Abdelfatteh. (2010). Issues in the education of English for specific purposes in the Tunisian higher education. ESP World, 2 (28), Volume 9, 1-20.

Hyland, K.(2006). English for specific purposes: An advanced resource book. New York, NY: Routledge.

Joyner, R. L., Rouse, W. A., \& Glatthorn, A. A. (2013). Writing the winning thesis or 
dissertation: A Step-by-step Guide (3rd Ed.). Thousand Oaks, California: Corwin.

Khalifa, R.M. (2016). The effectiveness of Using Think- Pair - Share Strategy on developing eleventh graders' writing skills in Rafah Governmental Schools. Gaza: Al-Azhar University - Gaza

Latief, M. A. (2013). Research methods on language learning: An introduction. Malang: State University of Malang Press.

Martina, F., Syafryadin, S., \& Utama, J. A. (2020). The Practice of extensive reading among EFL learners in tertiary level. Yavana Bhasha: Journal of English Language Education, 3(2), 56-72.

Martina, F., Syafryadin, S., Rakhmanina, L., \& Juwita, S. (2020). The effect of time constraint on student reading comprehension test performance in narrative text. Journal of Languages and Language Teaching, 8(3), 323-329.

Mothejzíková, J. (2014). English for specific purposes with regard to the use of ELearning. Published Dissertation. Czech Republic: Univerzita Karlova v Praze.

Mu'in, F. et al. (2018). Investigating teacher professional development: English teachers' learning activities as learners. Asian EFL Journal Research Articles. 20(12), 2.

Nugraha, A.Y. (2018). The influence of Think-Pair-Share (TPS) on students' reading narrative text (a quasi-experimental study at the eighth grade of SMPN 3 Kota Tangerang Selatan Academic Year 2015/2016). Unpublished Thesis. Jakarta: UIN Syarif Hidayatullah.

Nuttal, C. (2000). Teaching reading skills in a foreign language (New Edition ed.). London: Macmillan Heinemann.

Richards, J. C., \& Rodgers, T.S. (2001). Approaches and methods in English language teaching. New York: Cambridge University Press.

Susanti, M. (2017). The effectiveness of Think Pair Share Strategy toward students' reading comprehension at the second year of SMPN 1 Airtiris of Kampar Regency.

Wibowo, Y., Syafrizal, S., \& Syafryadin, S. (2020). An analysis of English teachers' strategies in teaching reading comprehension. JALL (Journal of Applied Linguistics and Literacy), 4 (1), 20-27

Yunita, L.R., Suharsono, and Munir, A. (2017). Readability in classroom practice of report text as reading material of eleventh graders. Journal of English Language and Literature December 2017 8(3), 673. 